RFP-1626

February 12, 1971

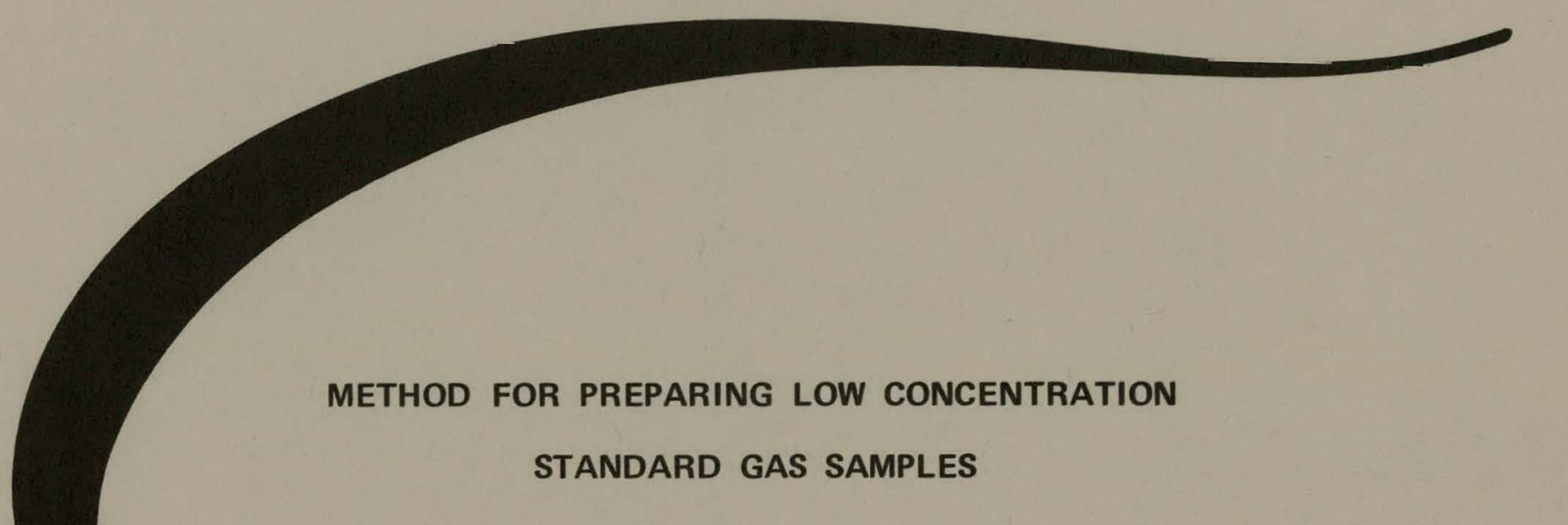

Daniel J. Fehringer

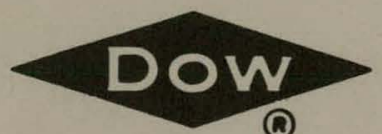

THE DOW CHEMICAL COMPANY

ROCKY FLATS DIVISION

P. O. BOX 888

GOLDEN, COLORADO 80401

U.S. ATOMIC ENERGY COMMISSION

CONTRACT AT(29-1)-1106 


\section{DISCLAIMER}

This report was prepared as an account of work sponsored by an agency of the United States Government. Neither the United States Government nor any agency Thereof, nor any of their employees, makes any warranty, express or implied, or assumes any legal liability or responsibility for the accuracy, completeness, or usefulness of any information, apparatus, product, or process disclosed, or represents that its use would not infringe privately owned rights. Reference herein to any specific commercial product, process, or service by trade name, trademark, manufacturer, or otherwise does not necessarily constitute or imply its endorsement, recommendation, or favoring by the United States Government or any agency thereof. The views and opinions of authors expressed herein do not necessarily state or reflect those of the United States Government or any agency thereof. 


\section{DISCLAIMER}

Portions of this document may be illegible in electronic image products. Images are produced from the best available original document. 


\section{LEGAL NOTICE}

This report was prepared as an account of work sponsored by the United States Government. Neither the United States nor the United States Atomic Energy Commission, nor any of their employees, nor any of their contractors, subcontractors, or their employees, makes any warranty, expressed or implied, or assumes any legal liability or responsibility for the accuracy, completeness or usefulness of any information, apparatus, product or process disclosed, or represents that its use would not infringe privately owned rights.

Printed in the United States of America

Available from the

National Technical Information Service

U. S. Department of Commerce

Springfield, Virginia 22151

Price: Printed Copy \$3.00: Microfiche $\$ 0.65$ 


\title{
METHOD FOR PREPARING LOW CONCENTRATION STANDARD GAS SAMPLES
}

\author{
Danie/ J. Fehringer
}

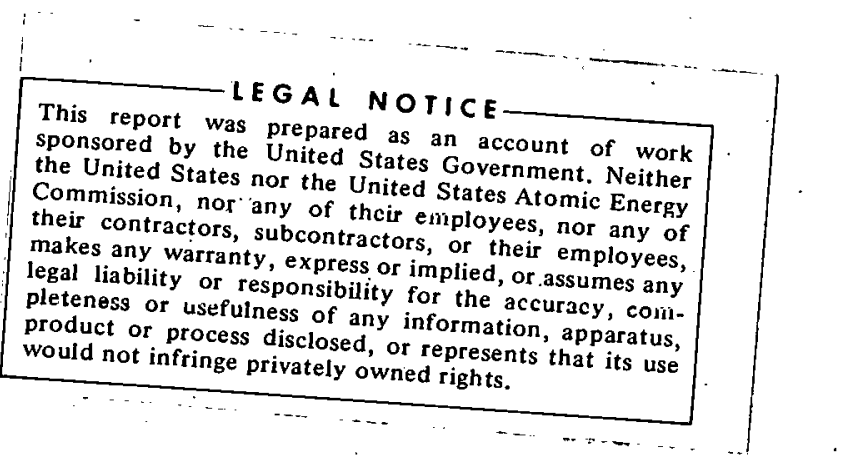

\section{THE DOW CHEMICAL COMPANY \\ ROCKY FLATS DIVISION \\ P. O. BOX 888 \\ GOLDEN, COLORADO 80401}

Prepared under Contract AT(29-1)-1106

for the

Albuquerque Operations Office

U. S. Atomic Energy Commission 
RFP-1626 


\section{CONTENTS}

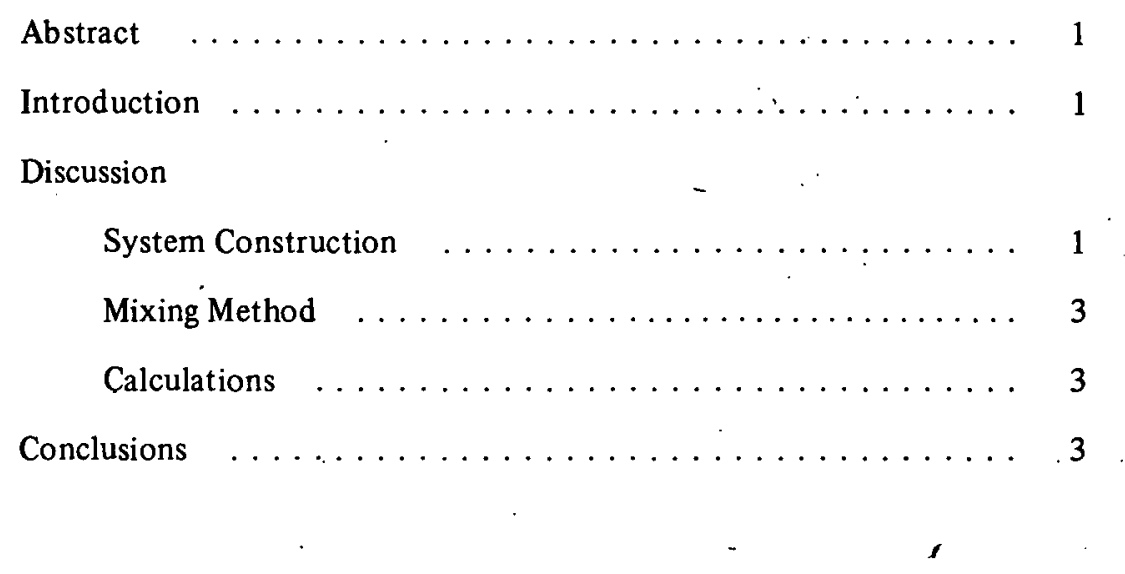


RFP-1626 


\title{
METHOD FOR PREPARING LOW CONCENTRATION STANDARD GAS SAMPLES
}

\author{
Daniel J. Fehringer
}

\begin{abstract}
A high precision method of preparing gas mixtures is described. Mixtures with concentrations as low as 10 parts per million can be readily prepared, as well as multicomponent mixtures. These gas samples serve as standards in the calibration of mass spectroscopy and gas chromatography equipment, and are prepared with accuracy traceable to national standards.
\end{abstract}

\section{INTRODUCTION}

Low concentration gas samples of accurately known composition are needed to serve as standards in the calibration of mass spectroscopy and gas chromatography equipment. Such gas samples must be prepared with an accuracy traceable to national standards.

Recently, the Physical Metrology Laboratory group explored a method of preparation. The method is based on the displacement of an accurately known volume of gas from a cylinder at constant pressure and constant temperature. The number of moles of the gas displaced into the mixing manifold can then be determined, and after the addition of a number of gases, the molar percentage of each gas present can be easily calculated.

\section{DISCUSSION}

\section{System Construction:}

The system constructed to prepare the mixtures is shown schematically in Figure 1.

For the addition of smaller component gases, a small cylinder (1) provided an advantage in determining accurate displacement data. For the addition of the carrier gas, a large cylinder (2) was used. (See Figures 2 and 3.)

The maximum displacement of the large cylinder (2) is 500 cubic centimeters $\left(\mathrm{cm}^{3}\right)$, accurate to within $\pm 0.1 \mathrm{~cm}^{3}$. The pressure gauge on the cylinder is accurate to within \pm 0.1 pounds per square inch absolute (psia). The smaller cylinder has a maximum displacement of $16 \mathrm{~cm}^{3}$, accurate to within $\pm 10^{-3} \mathrm{~cm}^{3}$. For this cylinder, the pressure gauge was accurate to within \pm 0.05 psia.

FIGURE 1. System Constructed for Mixture Preparation.

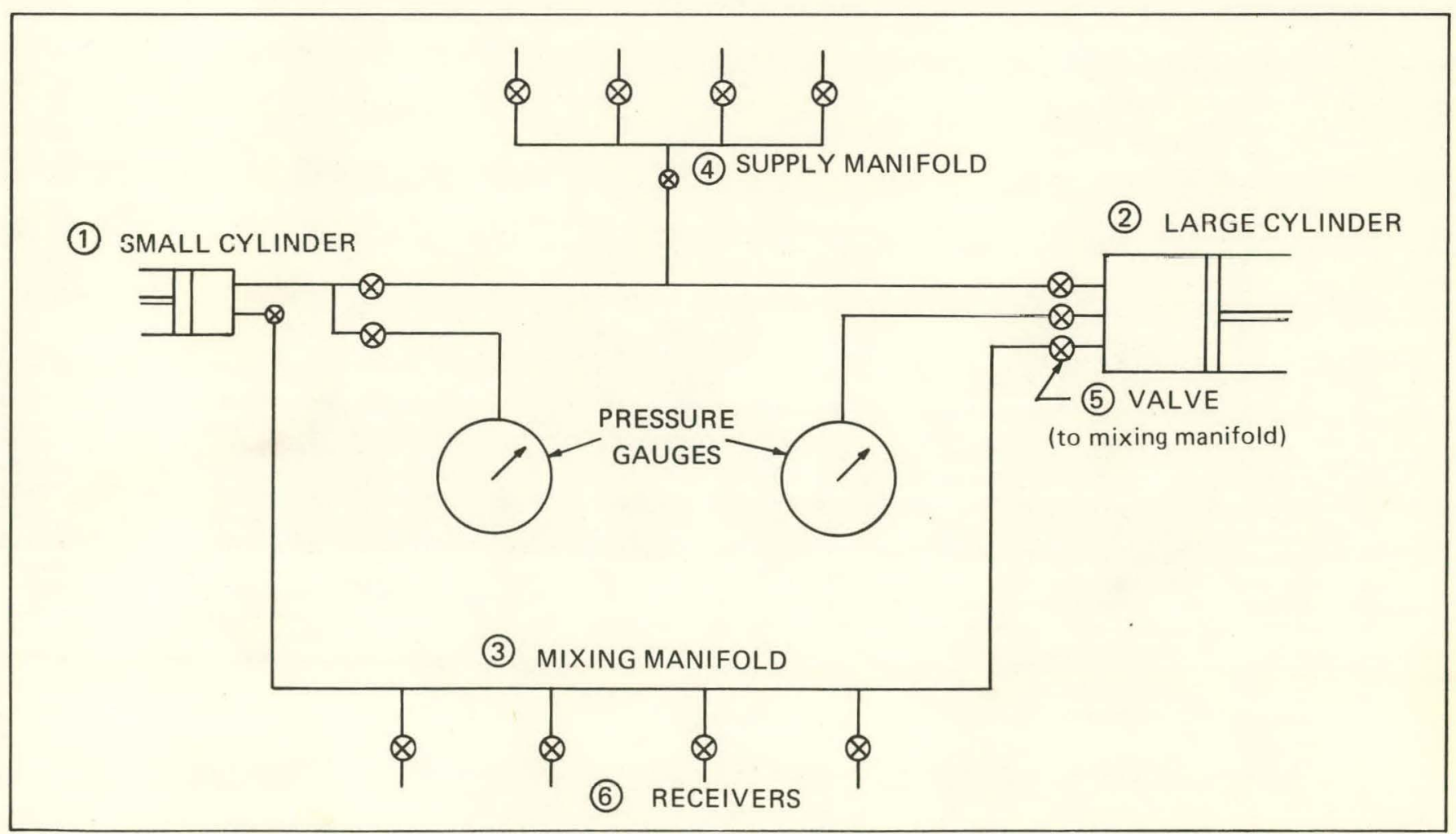




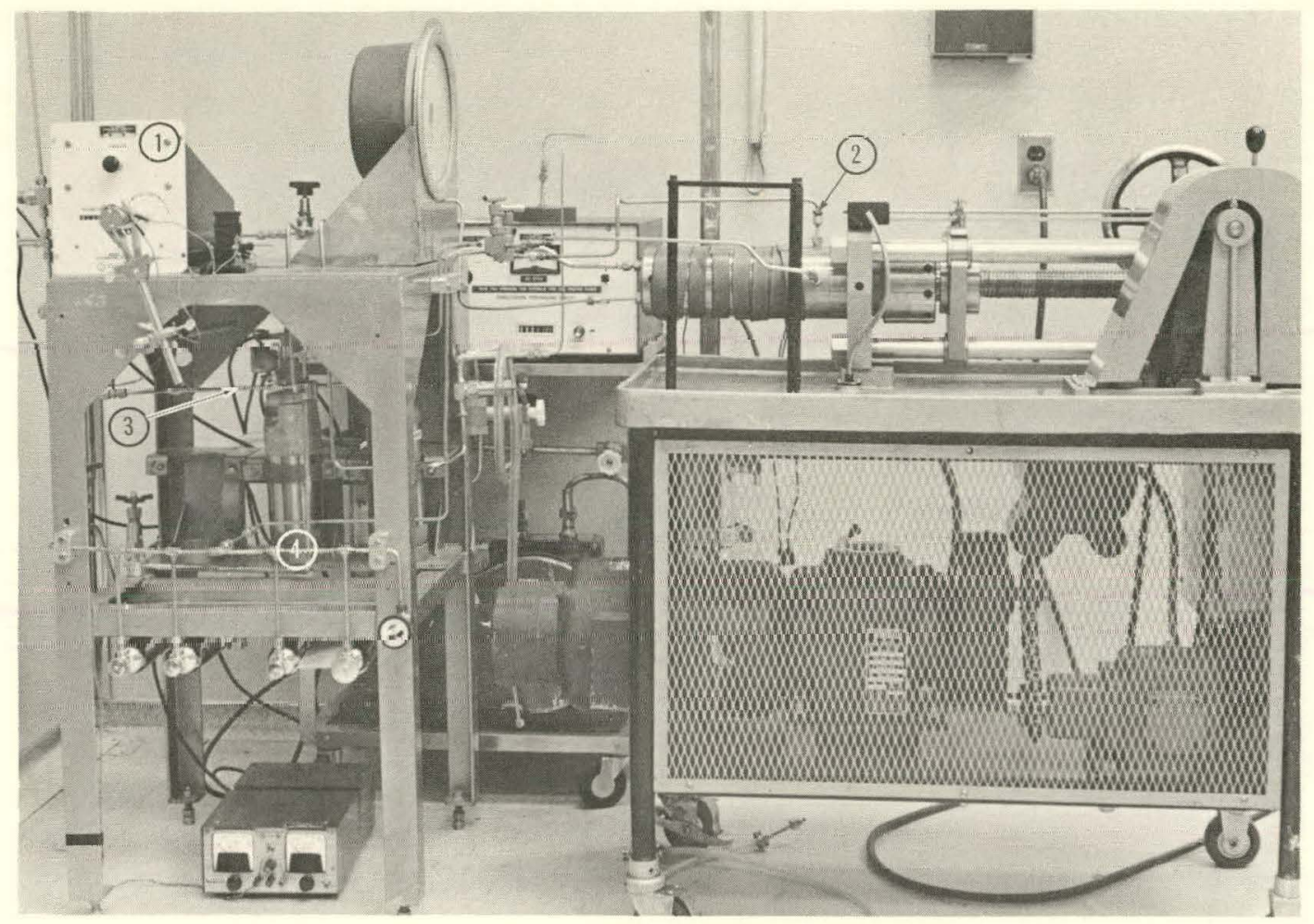

FIGURES 2 and 3. Details of Mixing System.

1. Small cylinder.

2. Large cylinder.

3. Mixing manifold.
4. Supply manifold.

5. Valve (to mixing manifold).

6. Receivers.

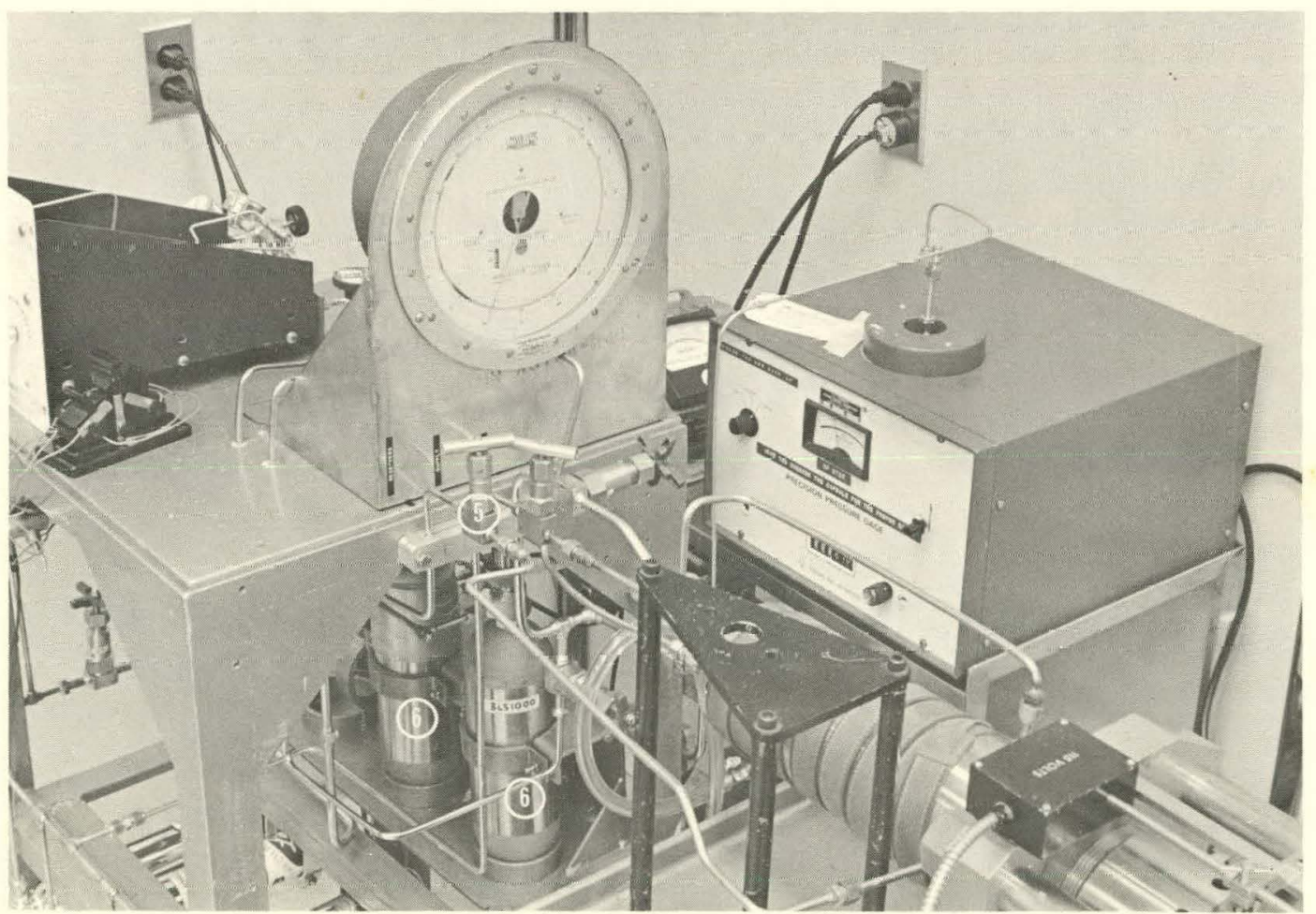


TABLE I. Calculated Data for Typical Gas Mixture.

\begin{tabular}{lcc}
\multicolumn{1}{c}{ Gas } & $\left.\begin{array}{c}\text { Pressure } \\
\text { pounds per square } \\
\text { inch absolute }\end{array}\right)$ & $\begin{array}{c}\text { Volume } \\
\text { (cubic centimeters) }\end{array}$ \\
\cline { 3 - 3 } Nitrogen $\left(\mathrm{N}_{2}\right)$ & 10.83 & 4.32 \\
Carbon Dioxide $\left(\mathrm{CO}_{2}\right)$ & 30.11 & 15.12 \\
Hydrogen $\left(\mathrm{H}_{2}\right)$ & 13.20 & 1.06 \\
Argon (Ar) & 25.54 & 6.05 \\
Helium (He) & 96.36 & 502.32 \\
Helium (He) & 95.98 & 501.01
\end{tabular}

\begin{tabular}{lr} 
Z & \multicolumn{1}{c}{$\mathrm{PVZ}^{-1}$} \\
0.999 & \\
0.990 & 46.83 \\
1.001 & 459.86 \\
0.999 & 13.98 \\
1.000 & 154.67 \\
1.000 & $48,403.56$ \\
& $48,086.94$
\end{tabular}

\begin{tabular}{c} 
Concentration \\
\hline 482 parts per million \\
0.473 percent \\
144 parts per million \\
0.159 percent \\
99.30 percent
\end{tabular}

Mixing Method:

A constant pressure displacement of gas is achieved in the following manner. Evacuate the entire system to a pressure of 10 microns or less. Isolate the mixing manifold from both cylinders, and the large cylinder from the supply manifold. Charge the smaller cylinder to a convenient pressure with one of the minor component gases, and then isolate the cylinder from the supply.

Start a slow compression of the cylinder and open slightly the valve between the cylinder and the mixing manifold so that a constant pressure within the cylinder can be maintained. When the desired volume of gas has been displaced into the manifold, stop the compression and close the valve.

Evacuate the cylinder and the supply manifold and add the other minor component gases in a similar manner. After all minor component gases have been added, introduce the carrier gas from the larger.cylinder. The larger cylinder permits a larger volume to be displaced at a higher pressure, resulting in the desired dilution after relatively few charges of the carrier gas.

A higher pressure for the carrier gas is important to prevent back-diffusion of the minor component gases when the valve to the mixing manifold is opened. Table I gives the calculated data for typical gas mixtures.

\section{Calculations:}

For most mixtures, pressures of the minor component gases do not exceed 30 psia. The pressure of the carrier gas does not exceed 100 psia and in this pressure range, the gases are assumed to follow the equation:

$$
P V=n Z R T
$$

Where: $\mathrm{P}=$ pressure

$\mathrm{Z}=$ compressibility ${ }^{1}$

$\mathrm{V}=$ volume

$\mathrm{R}=$ gas constant

$\mathrm{n}=$ number of moles of gas $\mathrm{T}=$ temperature

The temperature is held constant at $293.1^{\circ} \mathrm{K}$, thus the number of moles of each gas present in the mixture is proportional to $\mathrm{PVZ}^{-1}$, where $\mathrm{V}$ now represents the volume displaced from the cylinder. The molar percentage of any component gas can be calculated from the following formula:

$$
\text { Percent }_{j}=\frac{\mathrm{P}_{\mathrm{j}} \mathrm{V}_{\mathrm{j}} \mathrm{Z}_{\mathrm{j}}^{-1}}{\sum_{\mathrm{i}=1} \mathrm{PiVi}_{\mathrm{i}}{ }^{-1}}(100) \mid \mathrm{T}=293 .{ }^{\circ} \mathrm{K}
$$

In the formula, $\mathrm{P}_{\mathbf{j}} \mathrm{V}_{\mathbf{j}} \mathrm{Z}_{\mathrm{j}}{ }^{-1}$ represents the $\mathrm{jth}$ component of the mixture, and the summation is the sum of the $\mathrm{PVZ}^{-1}$ products of all gases' in the mixture.

\section{CONCLUSIONS}

Gas mixtures of 1000 parts per million (ppm) can be prepared with an accuracy of at least 1 percent using this method, and mixtures of $50 \mathrm{ppm}$ have an accuracy of 5 percent or better. Gas mixtures prepared by this method have been analyzed by mass spectroscopic and gas chro. matographic methods, using commercially available standards for reference. The results of these analyses compare favorably with the calculated results.

Experiments are being conducted by the Quality, Physical Metrology Laboratory group to determine the effects of adsorption of the component gases on the accuracy of the mixtures. Attempts are also being made to determine the compressibility factors of gases for which this information is not available.

\footnotetext{
${ }^{1}$ The expression $\mathrm{Z}=\mathrm{PV} / \mathrm{RT}$ is defined by Hilsenrath et al. Tables of Thermodynamic and Transport Properties. Pergamon Press, Incorporated, New York, 1960.
} 